\title{
VERIFICATION OF SPRAYED CLAY TECHNOLOGY WITH RESPECT TO THE GEOLOGICAL DISPOSAL OF RADIOACTIVE WASTE
}

\author{
Jiř́ SVOBODA, Jiřŕ ŠŤÁSTKA* and Jan SMUTEK \\ Czech Technical University in Prague, Faculty of Civil Engineering, Centre of Experimental Geotechnics, \\ Thákurova 7, 166 29, Prague, Czech Republic \\ *Corresponding author's e-mail: jiri.stastka@fsv.cvut.cz
}

\begin{tabular}{l} 
ARTICLE INFO \\
\hline Article history: \\
Received March 2013 \\
Accepted 20 Janury 2014 \\
Available online 25 February 2014 \\
\hline Keywords: \\
Bentonite \\
Shotclay \\
Deep radioactive waste repository \\
Backfill \\
Buffer
\end{tabular}

\section{ABSTRACT}

The investigation of sprayed clay technology has been underway at the Josef Underground Laboratory for a number of years. This technology was developed principally with respect to the backfilling of shafts and galleries in deep repositories providing access to disposal wells containing high-level long-lived radioactive waste. At present research is being focused on the use of this technology to fill the space between the spent fuel container and the wall of the disposal well. This paper describes experience gained from the various stages of the research including the selection of a suitable spray material and the testing and modification of the equipment employed and presents the results of a selection of shot clay mixture tests.

\section{INTRODUCTION}

Deep geological repositories are designed to isolate waste from the surrounding environment for a period of several hundred thousand years; therefore a multi-barrier system is required so as to effectively isolate the waste. Figure 1 shows a model of the repository according to the Swedish concept. It is currently envisaged that the spent fuel canister will be surrounded by prefabricates made of highlycompacted bentonite (buffer); however a barrier consisting of such blocks has the disadvantage of featuring a large number of discontinuities, i.e. joints. Research suggests that the discontinuities will become sealed due to the self-healing ability of bentonite. However the possibility cannot be discounted that even following self-sealing, preferential paths may remain which might allow radionuclide migration. As part of the current research programme, advanced shot clay technology is being developed which should allow for the mitigation of the number of discontinuities and thus enhance the safety of the disposal concept.

A range of bentonite sealing barrier (buffer and backfill) technologies are being developed in the framework of a number of national programmes in different countries and relating to various host rock environments under consideration for repository construction, e.g. salt formations (Germany, USA), granite (Sweden, Japan, Switzerland, Canada,), plastic clay (Belgium) and clay stone (Switzerland, France). A number of countries have already begun the construction process (Finland) while others have launched siting and investigation programmes (Germany, Switzerland, Czech Republic) (IAEA, 2013).

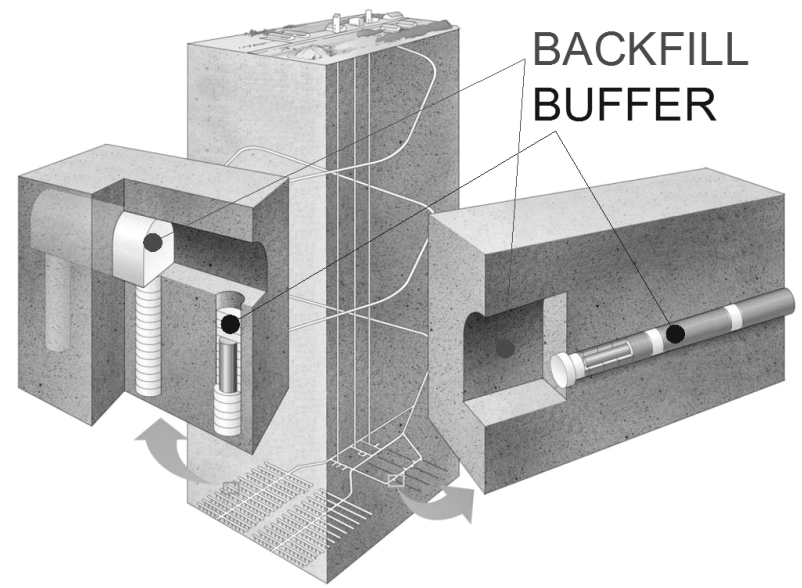

Fig. 1 Deep radioactive waste repository - KBS (vertical and horizontal) disposal systems (Posiva, 2008).

Several different technologies concerned with the application of bentonite are currently being tested one of which involves the use of prefabricated bentonite blocks produced by means of compacting bentonite powder under high pressure. The construction of the buffer from such blocks, however, has a number of disadvantages. The disposal well will be drilled into the host rock with a diameter which will enable the subsequent installation of both the container and the buffer. However, gaps will inevitably remain within the disposal well following container installation, the presence of which could cause e.g. the erosion and mass redistribution of the bentonite. One way of constructing a bentonite layer without the presence of gaps is to use spraying 
technology. Sprayed clay technology, also known as shotclay technology, is a relatively new concept as far as the Czech Republic is concerned and builds on the techniques and procedures employed for the pneumatic application of concrete mixtures (sprayed concrete). Two technological procedures are available for the application of the concrete material, i.e. the "dry" and "wet" methods (Polák et al., 2003). With regard to the dry process, the sprayed material is pneumatically transported by means of a hose to the spraying nozzle where it is hydrated at the moment it leaves the nozzle. The wet process, on the other hand, involves the transport of an already moistened mixture from the machine via a hose all the way to the spraying nozzle.

Sprayed clay technology has recently undergone thorough testing at several foreign locations, e.g. at AECL Canada (Atomic Energy of Canada Limited), SKB (Swedish Nuclear Fuel and Waste Management Co.) Sweden and the Radioactive Waste Management Funding and Research Centre (Tokyo, Japan). Certain institutions have attempted to develop a suitable technology for the application of sprayed buffers (Japan) and some others for sprayed backfill (Canada, Sweden). The aim of the research abroad was to test different materials and to compare their dry densities following application (Dixon, 2003; Kobayashi et al., 2008).

In order to prevent radionuclide migration the sealing material must have a very low level of water permeability. Since it has been established that permeability is strongly dependent on the density of a material, the dry density and water content of the material make up the most important parameters monitored during the emplacement procedure. All the most important material parameters in terms of the prevention of potential radionuclide migration depend on these two key values. An assessment of the selected materials prior to technological testing was carried out; the relationship between permeability and dry density was examined and subsequently established within this phase of the research. This then allowed the rapid verification of the suitability of both the sprayed material and the technology employed for use in deep repositories by means of the simple checking of the dry density value of the material.

The objective of the research described in this paper was to test a Czech bentonite (Ultra bentonite UB) in order to determine conditions for the achievement of both the maximum compaction of the material and the required dry density values.

\section{TESTING HISTORY}

Shotclay technology is primarily being developed for use in the unique underground conditions of deep radioactive waste repositories. Research focusing on the development of sprayed clay technology has been underway at the CEG since 2007.

In the first phase of the research (2007 to 2009) two spraying machines for the dry application of clays were tested, i.e. the SSB24 and SSB 14 DUO machines produced by Filamos Ltd. (Pacovský and Št'ástka, 2009). The second phase of the research, which commenced in 2010, concerns the ongoing testing of the Mixokret machine produced by Strojstav n.p.

The objective of the first phase was to develop spraying technology for the application of backfill material for deep repository access tunnels. Of the two existing technological procedures available, the dry process was selected for the delivery of sprayed backfill. The eventual backfilling of deep repository access galleries will consist of two stages: the greater part of the space will be filled by means of compaction machines and the uppermost part (where there will not be enough space available for the compacting machine) will be filled using the spray technique.

Research work concentrated principally on the optimisation of the technology involved (machine support and materials), attaining sufficiently high dry density levels and the limiting of the fallout of the sprayed material and dust. Clearly, water plays a key role in the spraying process, i.e. in terms of the amount required (rate to mass of the applied clay), pressure and distribution within the clay material.

As far as backfilling is concerned, the spraying assembly consists of five components: the air compressor, the spraying machine itself (finally the SSB 14 DUO was selected), the nozzle, the hoses and the water flow regulator. The technology developed for the purposes of backfilling was successfully tested by means of a real-scale experiment conducted at the Josef Underground Laboratory where a short gallery was filled with bentonite using the procedure outlined above. The level of compaction attained was deemed sufficient for backfilling purposes.

The testing of the wet spraying process for the application of bentonite employing the Mixokret machine has been underway since 2010. One significant advantage of this machine is that the material is more uniformly wetted which leads to a more uniform final application. It is assumed that since higher output spraying pressures can be achieved employing this machine, the bentonite applied will have a higher level of compaction than that achievable using the SSB-type machines. The higher the level of material compaction, the more a number of important geotechnical parameters can be guaranteed including hydraulic conductivity and swelling pressure, both of which are essential in mitigating the potential leakage of radionuclides from the repository. Once the sprayed material meets the required property requirements it can be used as buffer material.

\section{TESTED MATERIAL}

Based on availability and on the results of laboratory testing, Ultra-Bentonite (UB) in granulated form was selected as the most suitable test material. 
Table 1 Basic properties of Ultra-Bentonite (average values from the CEG's database).

\begin{tabular}{lc}
\hline Water content on liquid limit & $210 \%$ \\
Water content on plastic limit & $61 \%$ \\
Specific density & $2.82 \mathrm{Mg} / \mathrm{m}^{3}$ \\
Hydraulic conductivity at $1.5 \mathrm{Mg} / \mathrm{m}^{3}$ & $4 \mathrm{E}-13 \mathrm{~m} / \mathrm{s}$ \\
Swelling pressure at $1.5 \mathrm{Mg} / \mathrm{m}^{3}$ & $3.4 \mathrm{MPa}$ \\
Thermal conductivity at $1.45 \mathrm{Mg} / \mathrm{m}^{3}$ and water content $8 \%$ & $0.378 \mathrm{~W} / \mathrm{mK}$ \\
\hline
\end{tabular}

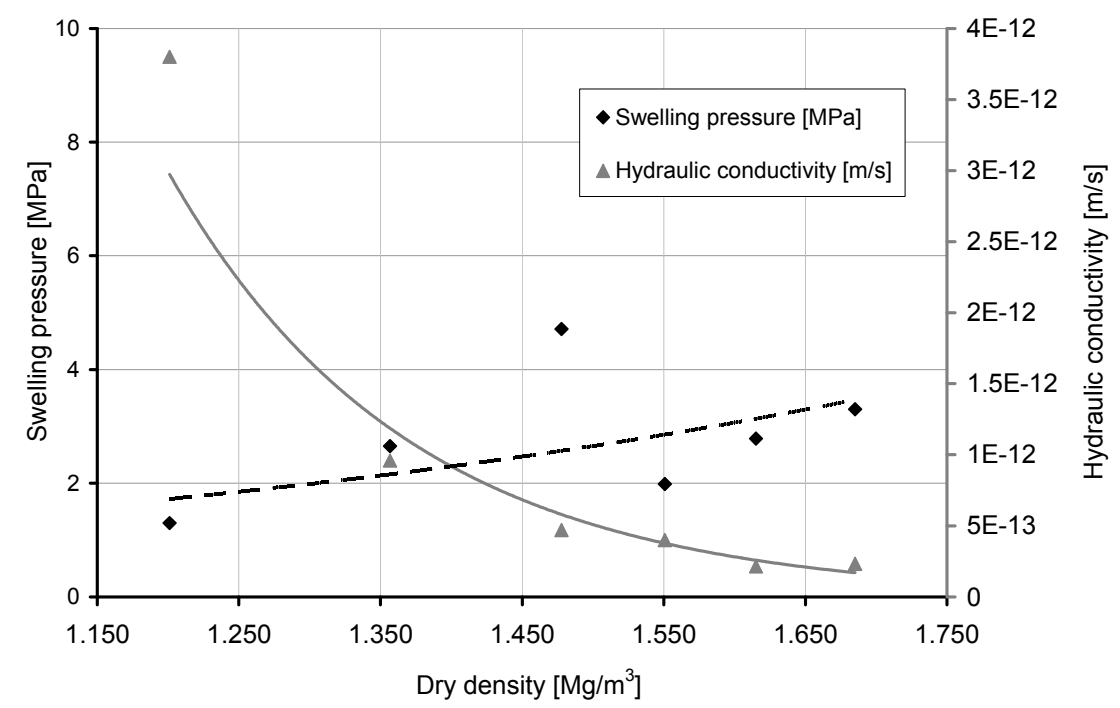

Fig. 2 Dependence of swelling pressure and hydraulic conductivity on dry density for the UB materiál.

UB is Czech kalcium magnesium bentonite with a montmorillonite content of between 65 and $80 \%$ which is characterised by both good swelling and selfhealing abilities and minimum permeability. Basic properties of this bentonite can be found in Table1. The availability of the material has been verified by the Keramost Ltd. bentonite treatment works (sufficient reserves exist for Czech deep repository purposes).

The laboratory testing of UB consisted of the detailed measurement of swelling pressure and hydraulic conductivity, the standard Proctor compaction test and grain size curve determination.

The required values for the backfill and buffer can be found in existing literature pertaining to the most advanced repository programmes (Finland, Sweden). For example, Rautioaho and KorkialaTanttu (2009) and SKB (2006) specified backfill and buffer requirements with backfill parameters determined as follows: hydraulic conductivity $<10^{-11} \mathrm{~m} / \mathrm{s}$ and swelling pressure $>0.1 \mathrm{MPa}$. Buffer requirements are stricter than those for the backfill and require higher quality standards (dry density) in terms of application; limit values for the buffer consist of: hydraulic conductivity $<10^{-12} \mathrm{~m} / \mathrm{s}$ and swelling pressure $>1 \mathrm{MPa}$.

At the CEG, the swelling pressure and hydraulic conductivity (dry density dependant) values were determined by means of a series of laboratory tests. According to the results it is reasonable to expect that UB will fulfil buffer safety requirements when compacted to a dry density in excess of $1.3 \mathrm{Mg} / \mathrm{m}^{3}$. Hydraulic conductivity $(\mathrm{K})$ is determined according to ČSN CEN ISO/TS 17892-11. An evaluation of hydraulic conductivity is carried out on the same samples used for the evaluation of swelling pressure. The calculation of hydraulic conductivity derives from Darcy's law of the velocity of flow:

$v=K . i$

where:

$\mathrm{v}$ - velocity of flow in the sample $[\mathrm{m} / \mathrm{s}]$,

$\mathrm{i}$ - hydraulic gradient $[\mathrm{m} / \mathrm{m}]$

where hydraulic gradient is:

$i=\frac{\Delta h}{\Delta l}$

where:

$\Delta \mathrm{h}$ - hydraulic head $[\mathrm{m}]$,

$\Delta \mathrm{l}$ - trajectory of a water particle in the sample [m]

Swelling pressure was tested simultaneously with hydraulic conductivity. The force generated by the saturated - swollen material is measured continually. Swelling pressure is calculated using the equation (3). 


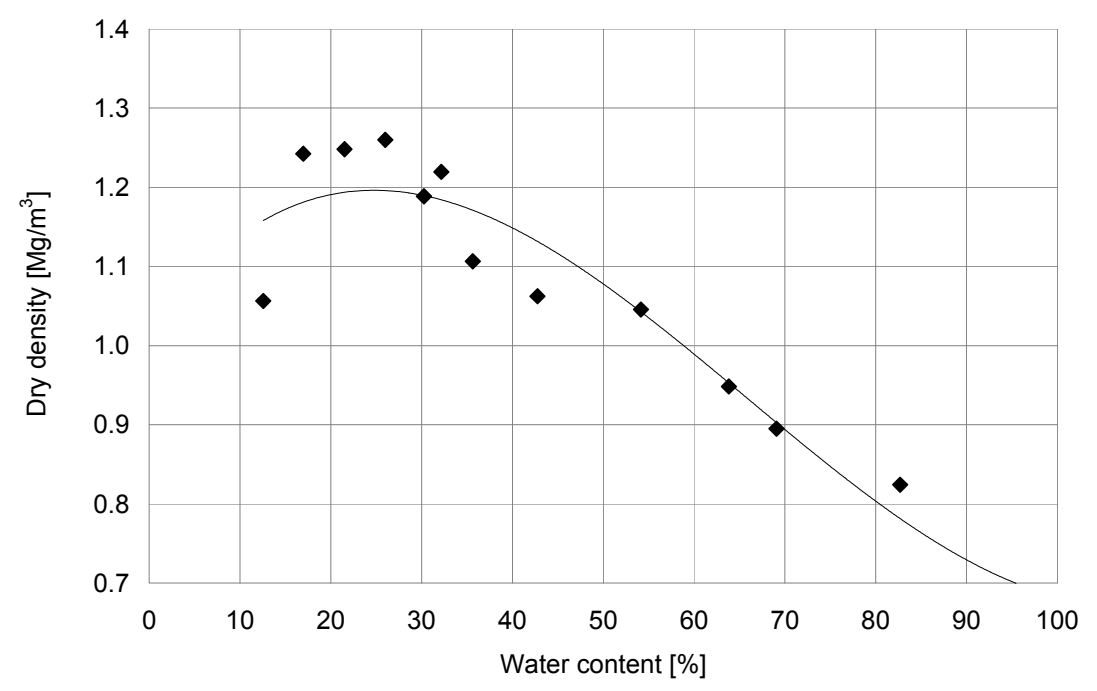

Fig. 3 Results of the proctor standard test for the UB material (results from two tests, 13 samples).

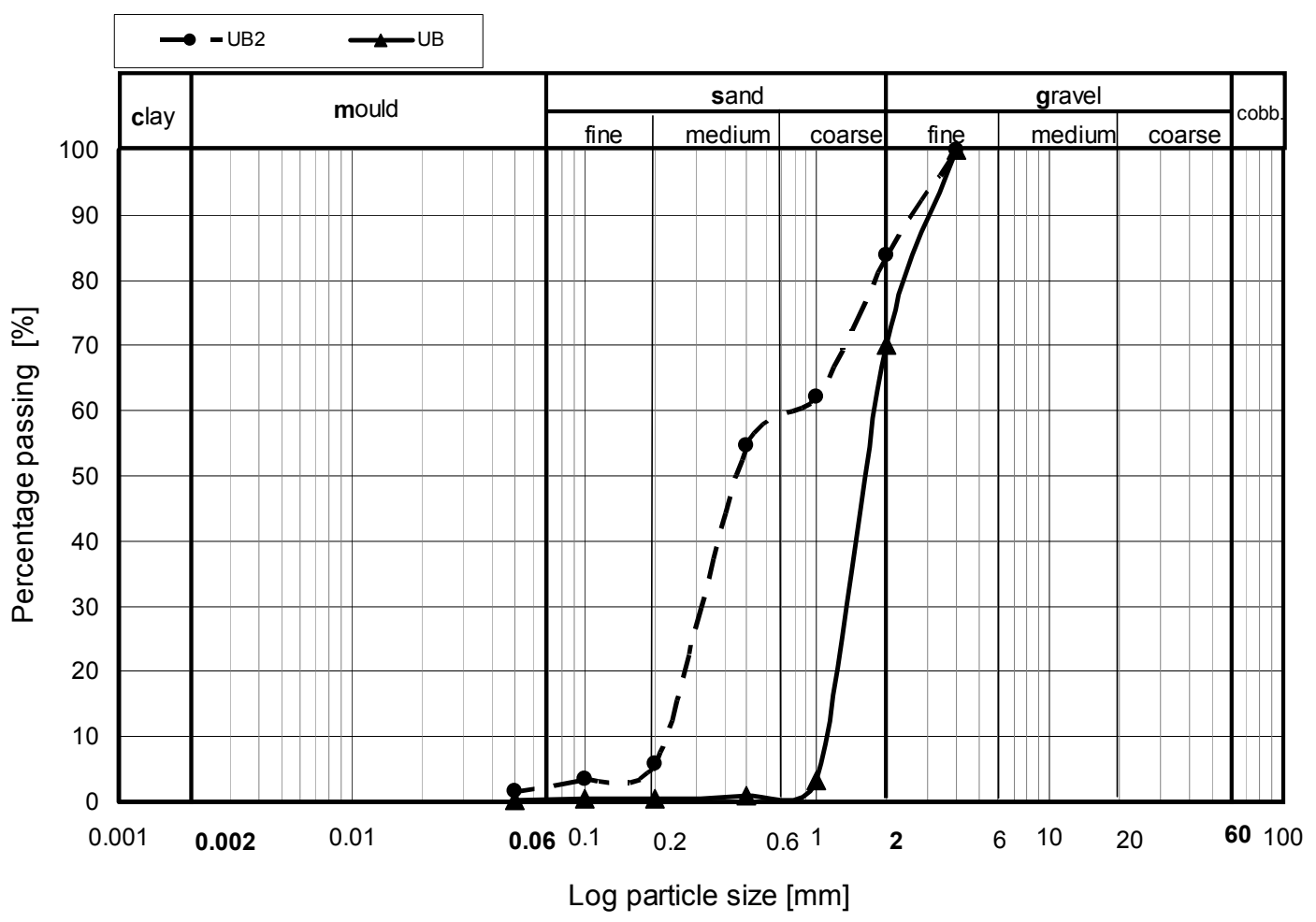

Fig. 4 The grain size curve of sprayed materials.

$\sigma_{s w}=\frac{F}{A}$

where:

$\mathrm{F}$ - measured force $[\mathrm{kN}]$,

A - perpendicular area of the sample to the direction of measured force $\left[\mathrm{m}^{2}\right]$

Representative values of swelling pressure and hydraulic conductivity are shown in Figure 2 . The graph shows the results of testing on 6 samples with different densities performed over a period of approximately 6 months.

The output of the standard Proctor compaction test consists of the dependence of dry density on water content. Once this relationship has been defined, the optimum moisture content at which the maximum dry density of the material is achieved can be determined. The results of the Proctor test plotted in Figure 3 clearly indicate that the maximum compaction of UB can be achieved with a water content of between 20 

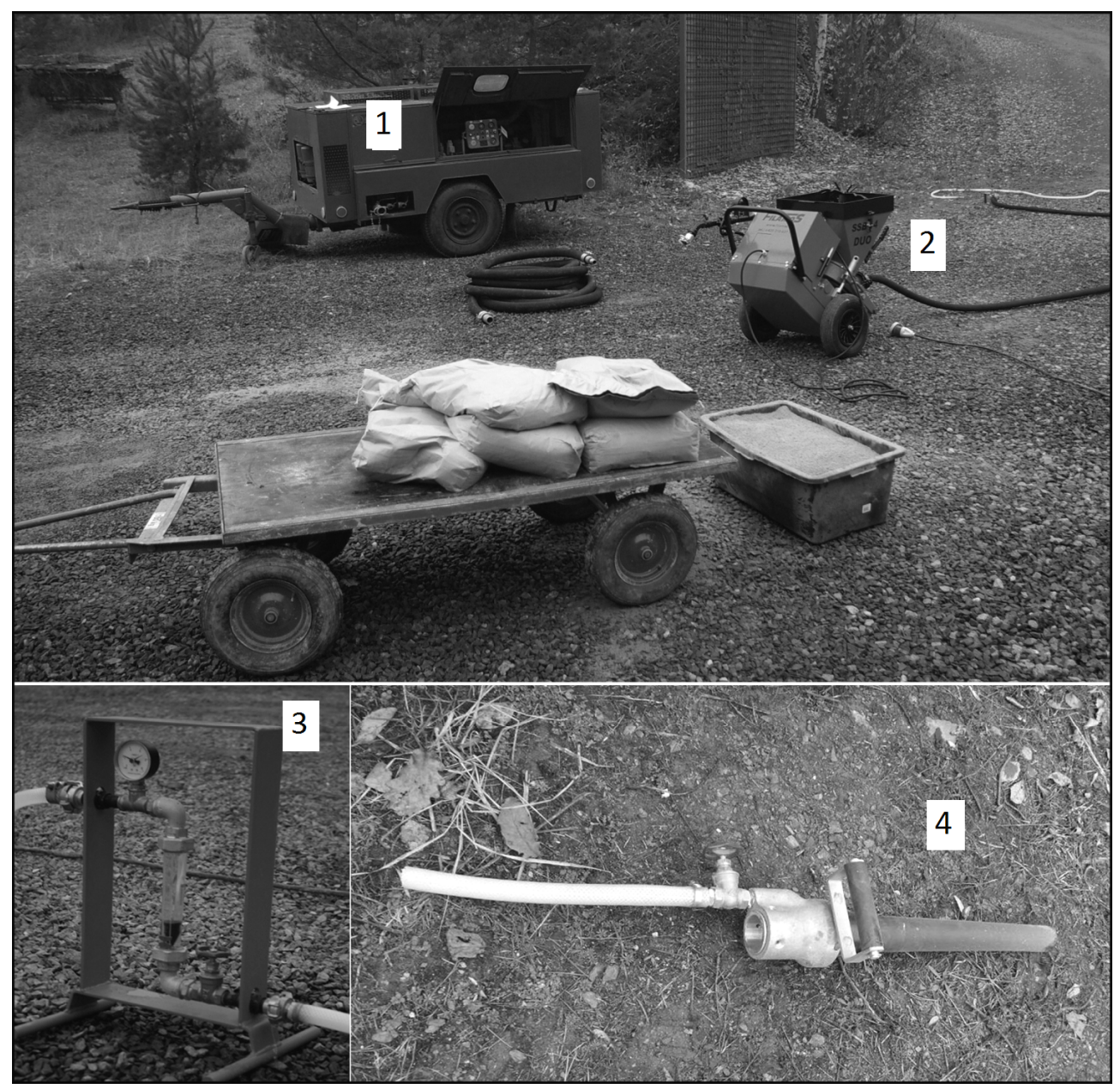

Fig. 5 The initial equipment for the dry process $(1$ - air compressor, 2 - SSB 14 DUO machine, 3 - flowmeter, 4 - spraying nozzle).

and $25 \%$. Since the initial moisture content of bentonite is significantly lower than this level, the material will have to be moistened before application in order to be able to attain the desired degree of compaction.

Figure 4 shows the grain size curves of the tested materials.

The equipment for the dry process used for shotclay application in the first phase of testing consisted of five components: an air compressor, the spraying machine (SSB 14 DUO), hoses, a water flow regulator and a spraying nozzle. The complete equipment is shown in Figure 5. The dry application process involved the pneumatic transportation of the dry spray material by means of a hose to the spraying nozzle and hydration at the moment the material exited the nozzle. A detailed drawing of the spraying machine is in Figure 6.

The spray assembly for the wet process consists of three main components: a compressor, which supplies compressed air for the pneumatic transport of the spray mixture from the mixing machine (Mixokret, Fig. 7), the mixing machine itself and the transport hose (including the nozzle). The standard spraying equipment was later supplemented with two additional components, i.e. a lever valve at the output of the spraying machine and a special spraying nozzle at the end of the transport hose.

The general application procedure consists of the following:

1. Assembly of the spraying equipment (compressor, Mixokret machine, transport hose)

2. The mixing of the bentonite material with water (liquid and/or frozen) and the pressurisation of the mixture inside the mixing machine

\section{Spraying}

The material inside the pressurised vessel (part of the mixing machine) is aerated by means of a paddle stirrer and mixed with water or crushed ice following which the material is pushed by the paddle stirrer into the outlet of the vessel. Once the vessel is pressurised to a maximum working pressure of $0.6 \mathrm{MPa}$ the lever valve is opened and the material is ejected. Vessel pressurisation and material ejection is repeated until the vessel is empty whereupon the machine is re-filled with the spray material and the spraying procedure, including the necessary mixing, continues. 

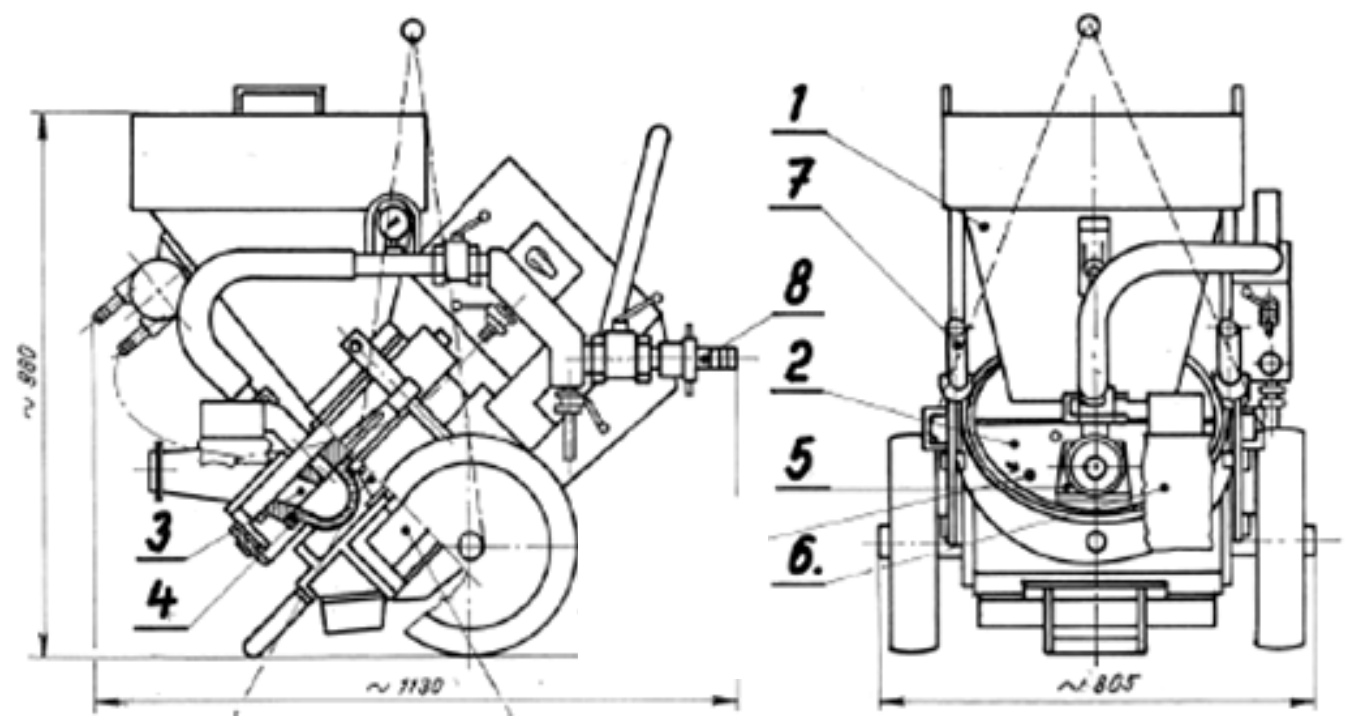

Fig. 6 Drawing of SSB 14 DUO machine (provided by Jiří Labuda, FILAMOS s.r.o.) (1 hopper, 2 - dosing head, 3 - sealing plate, 4 - dosing drum, 5 - air exhaust, 6 . dust exhaust, 7. clamping bolt, 8. air inlet).

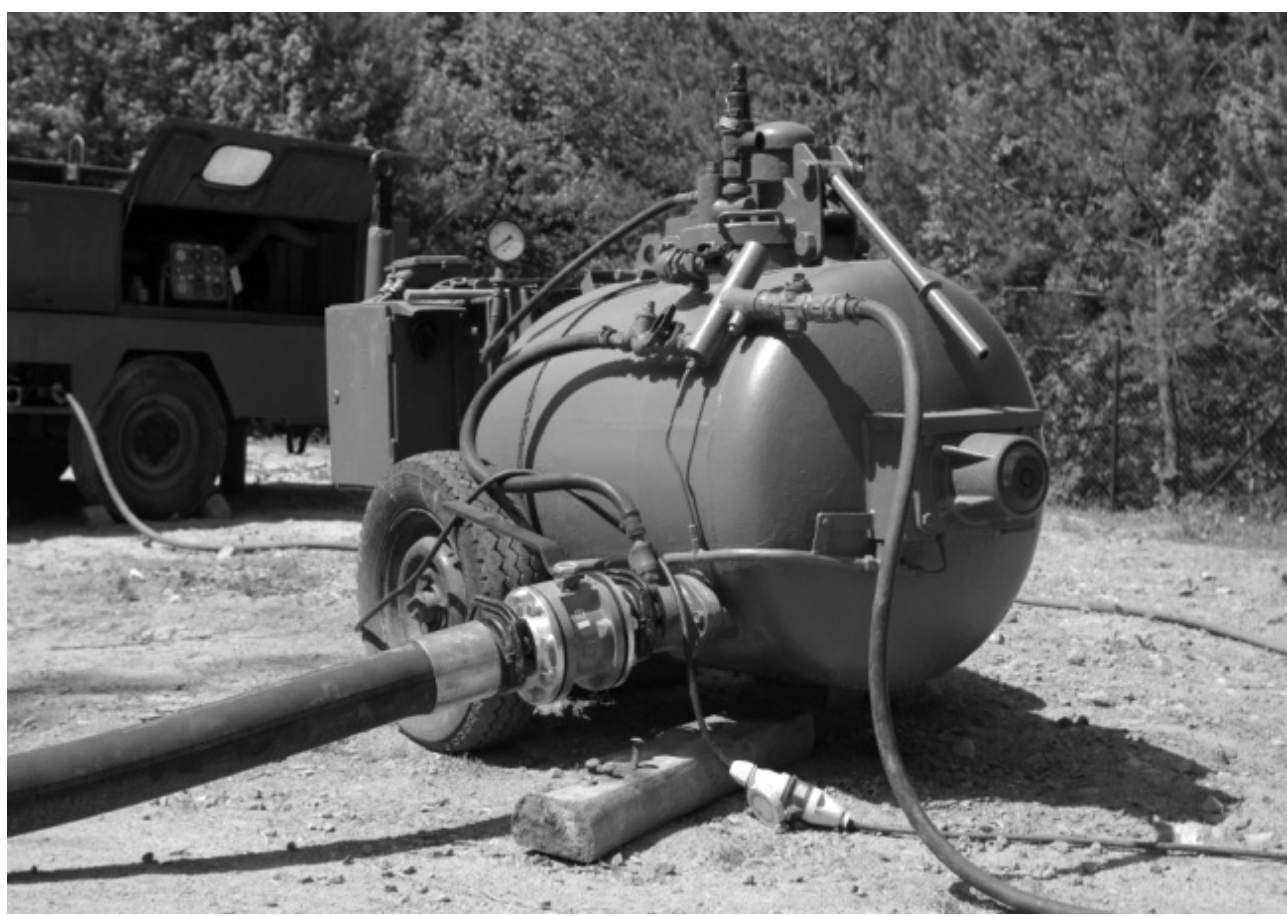

Fig. 7 Mixing machine (Mixokret).

\section{RESULTS}

It was found that the main indicator in terms of the success of the spraying technique is the level of dry density. Two basic sampling methods are available for the determination of dry density and water content following spraying. Cylindrical samples can be taken by means of core drilling or the material can be sprayed directly into sampling rings positioned on a testing wall (Fig. 8, Fig 9). A comparison of the two methods clearly showed that taking samples using a sampling ring is more effective than drill core sampling since samples using the latter method could be taken only from the top layer of the sprayed bentonite. Since the material is better compacted in this layer, it necessarily has a higher dry density which leads to an overestimation of average density throughout the material.

The optimum compaction level of bentonite is achieved with a water content of between 20 and $25 \%$ according to the Proctor compaction test. Bentonite in 


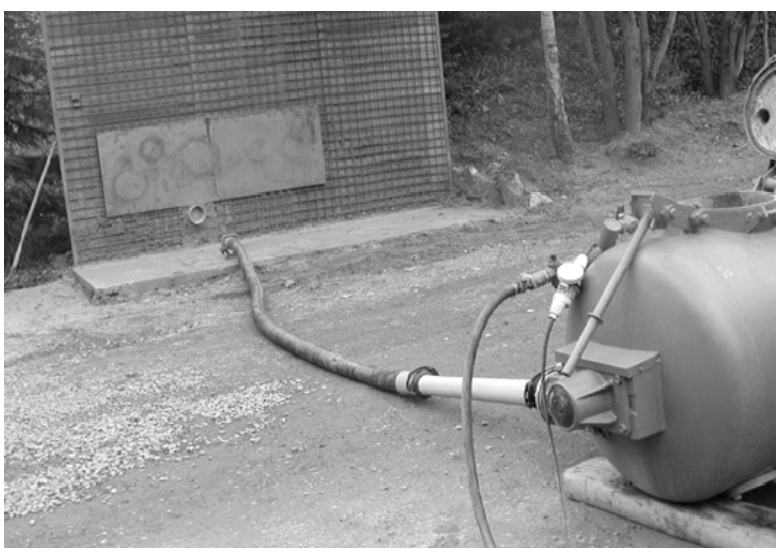

Fig. 8 Spraying machine with transport hose before spraying.

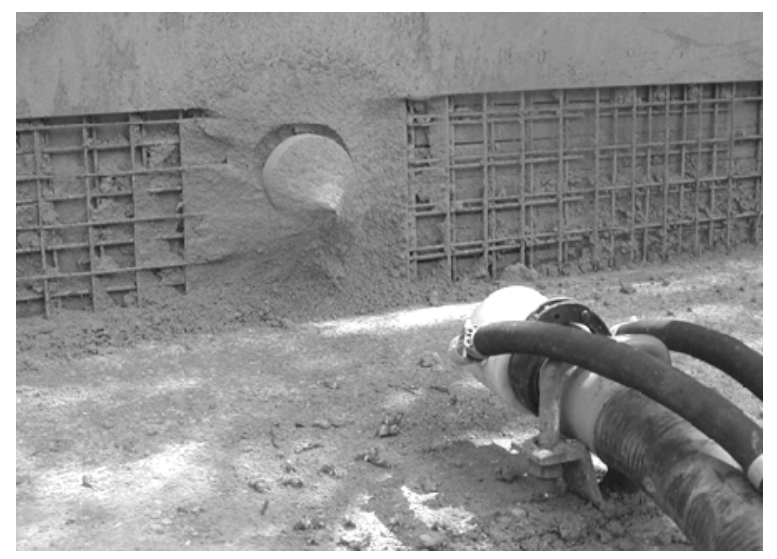

Fig. 9 Spraying nozzle and sampling ring after spraying.

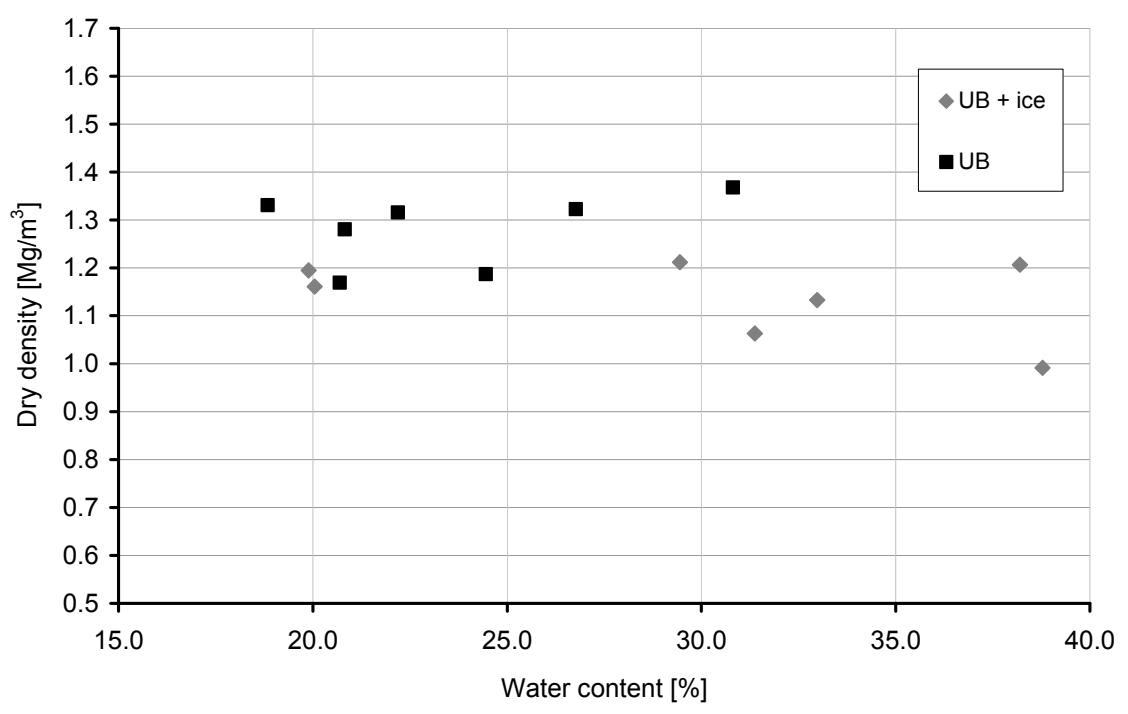

Fig. 10 Results of spraying tests for the standard UB material and UB with ice.

its natural state has a water content of approximately $8 \%$, therefore, it is necessary to introduce additional water in order to obtain an ideal sprayed material consistency.

Two wetting methods were tested, the first using liquid water and the second crushed ice. The main advantage of using ice is that it leads to better homogeneous moisture distribution within the material following mixing. The tests involved leaving the crushed ice to melt inside the mixing machine after mixing it with the bentonite. The test results are plotted in Figure 10. The final dry density values were generally similar for both processes; however, it is worth noting that in some cases the samples using ice exhibited slightly lower dry density values.

It was also expected that the presence of nonmelted ice would enhance the kinetic energy of the sprayed material and thus maximise the effect on compaction. In order to verify this assumption an attempt was made to spray the material with non- melted ice. Figure 11 shows the results of a total of three tests in which the material was sprayed with different degrees of melted ice. The results reveal that ice in the solid state in the mixture did not improve compaction. However, higher values of dry density were achieved using higher ratios of melted ice.

Following the testing of standard UltraBentonite, a new material, given the name UltraBentonite 2 (UB2), with a different particle size distribution was tested. However, dry density values were found to be no higher using this material (Fig. 10).

The results of the Kajima project (Kobayashi et al., 2008) were selected for comparison purposes. A method for the application of bentonite using the dry process was developed as part of this project. Dry density values of the tested bentonite of around $1.6 \mathrm{Mg} / \mathrm{m}^{3}$ (water content $20.2 \%$ after spraying) would fulfil all requirements for use as the backfill, buffer and both types of sealing barrier. 


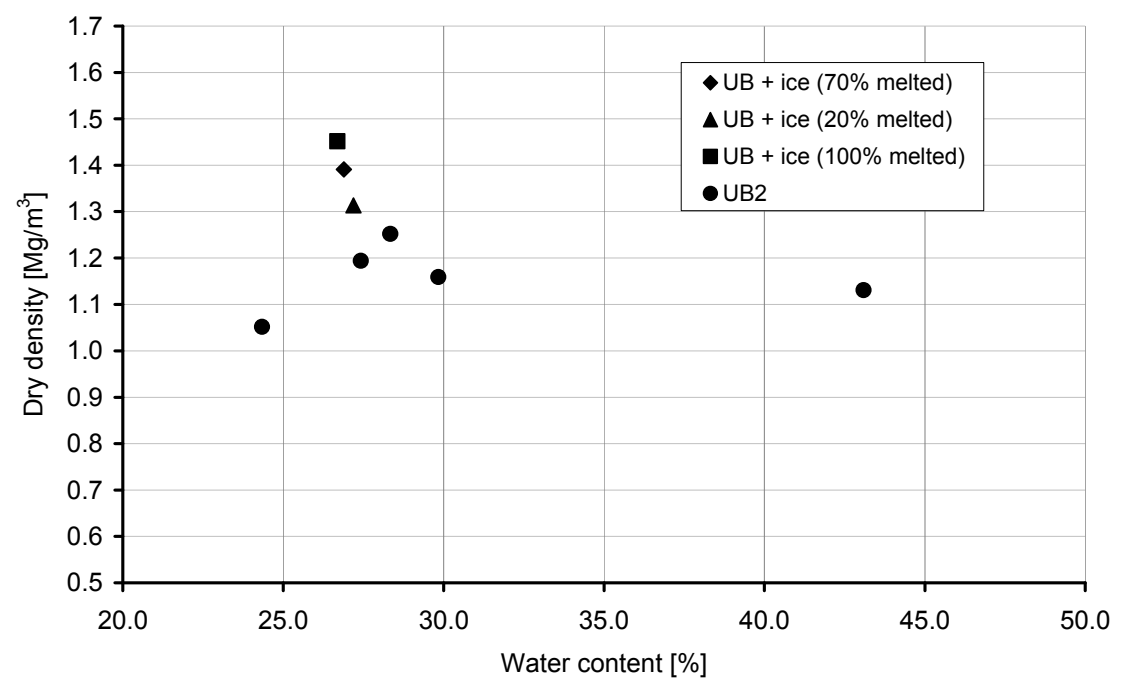

Fig. 11 Results of spraying tests for UB with crushed ice and UB2 material.

Subsequent testing employing the Mixokret machine will include testing under higher working pressures which will increase the kinetic energy of the sprayed material and thus ensure a higher level of material compaction. This should in turn lead to higher sprayed material dry density levels which will provide a broader safety margin.

\section{CONCLUSIONS}

Czech Ultra-Bentonite is, from the geotechnical point of view, suitable for the experimental testing of materials and techniques intended for use in underground RAW storage facilities. Following the modification of the spray components of the Mixokret machine, dry density values of around $1.3 \mathrm{Mg} / \mathrm{cm}^{3}$ were achieved. According to initial test results it can be assumed that shotclay technology is suitable for use in the construction of sealing barriers for RAW storage. However, the technology must first be verified under real repository conditions.

The results show that it is also possible to use crushed ice in order to increase the desired moisture content of the sprayed mixture. This technique ensures the more uniform distribution of moisture within the bentonite; however, it was found that leaving nonmelted ice in the mixture during application did not help in terms of achieving better compaction rates.

\section{ACKNOWLEDGEMENT}

This research is supported by CTU grant no. SGS10/242/OHK1/3T/11, by the Czech Ministry for Trade and Industry, Project no. FR-TI1/362 and by the Czech Radioactive Waste Repository Authority.

\section{REFERENCES}

Dixon, D.: 2003, Concept and technologies for backfilling a nuclear fuel Waste repository. AECL, report No: 06819-REP-01200-10103-R00

IAEA: 2013, Overview of disposal options - IAEA. Division of Nuclear Fuel Cycle and Waste Technology - IAEA. Iaea.org [online]. [cit. 2013-09-24]. Available from: http://www.iaea.org/OurWork/ST/NE/NEFW/Technic al_Areas/WTS/geologicaldisposal-options.htm

Kobayashi, I., Terada, K. and Nonaka, K.: 2007, Development of construction methods of the bentonite engineered barrier by the high/density shotclay system. Proceedings of the Special workshop at IDEON Science Park, Lund, Sweden.

Kobayashi, I., Toida, M. and Sakura, T.: 2008, Development of water content adjustment method using powdered ice and chilled bentonite: Application to the construction of bentonite engineered barriers by shotclay method. In: Science \& Technology, Series $\mathrm{n}^{\circ} 334$ (2008)-Andra [online].[cit.2013-09-24]. Available from: http://www.nantes2010.com/doc/pdf/lille/08_Kobayashi.pdf

Pacovský, J. and Št'ástka, J.: 2009, Development of sprayed backfill technology. In: Ecosystems and Sustainable Development VII. Southampton WIT Press, 523-533. DOI: $10.2495 / \mathrm{ECO} 090481$

Polák, P. et al.: 2003, Principles for the use of shotcrete, Český tunelářský komitét ITA/AITES, Praha, (in Czech).

Positiva: 2008, The principles for final disposal. POSIVA. www.posiva.fi [online]. 15.12. 2008 [cit. 2012-11-20]. Available from: http://www.posiva.fi/files/533/KBS3_en.jpg.

Rautioaho, E. and Korkiala-Tanttu, L.: 2009, Bentomap: Survey of bentonite and tunnel backfill knowledge, VTT Technical Research Centre of Finland, $121 \mathrm{pp}$.

SKB: 2006, (Svensk Kärnbränslehantering AB). Buffer and backfill process report for the safety assessment SRCan: Technical Report TR-06-18 [online].[cit. 201305-23]. ISSN 1404-0344. Available from: http://www.skb.se/upload/publications/pdf/TR-0618.pdf 